\title{
Interactions of Paracoccidioides brasiliensis with host cells: recent advances
}

\author{
Maria José Soares Mendes-Giannini · Juliana Leal Monteiro da Silva • \\ Julhiany de Fátima da Silva - Fabiana Cristina Donofrio - Elaine Toscano Miranda • \\ Patrícia Ferrari Andreotti · Christiane Pienna Soares
}

Received: 13 July 2007 / Accepted: 3 October 2007 / Published online: 17 October 2007

(C) Springer Science+Business Media B.V. 2007

\begin{abstract}
Host-fungal interactions are inherently complex and dynamic. In order to identify new microbial targets and develop more effective antifungal therapies, it is important to understand the cellular and molecular mechanisms of disease. Paracoccidioidomycosis provokes a variety of clinical symptoms, and Paracoccidioides brasiliensis can reach many tissues, but primarily attacks the lungs. The ability of the pathogen to interact with the host surface structures is essential to further colonization, invasion, and growth. Epithelial cells may represent the first host barrier or the preferential site of entry of the fungus. For this reason, interactions between P. brasiliensis and Vero/A549 epithelial cells were evaluated, with an emphasis on the adherence, induction of cytoskeletal alterations, and differential signaling activity of the various surface molecules. The adhesion to and invasion of epithelial cells by $P$. brasiliensis may represent strategies employed to thwart the initial host immune response, and may help in the subsequent dissemination of the pathogen throughout the body.
\end{abstract}

M. J. S. Mendes-Giannini ( $₫)$ · J. L. Monteiro da Silva ·

J. de Fátima da Silva · F. C. Donofrio .

E. T. Miranda · P. F. Andreotti - C. P. Soares

Departamento de Análises Clínicas, Faculdade de

Ciências Farmacêuticas, UNESP, R. Expedicionários do

Brasil, 1621, Araraquara, SP CEP 14801-902, Brazil

e-mail: giannini@fcfar.unesp.br
Keywords Paracoccidioides brasiliensis . Host-fungal interaction · Adhesion .

Cytoskeleton · Apoptosis · Virulence factors

\section{Introduction}

Paracoccidioidomycosis has a multiplicity of clinical presentations, from cutaneous to systemic forms, and can attack various tissues, especially in the lung [1]. Paracoccidioides brasiliensis and other fungi that cause systemic mycoses use a sequence of different mechanisms to become established in the host, from the first contact with host cells until the later stages of the disease. These mechanisms need to be better understood. In particular, those involved in dissemination are not at all clear; neither are the steps, by which the fungus crosses to the intravascular compartments of various organs [2,3]. The different clinical forms of the disease and the occurrence of asymptomatic infection may be a result of host-related factors, such as sex, age, and immunological status, as well as characteristics of the infecting agent, especially its virulence [4]. Fungi are non-motile eukaryotes that depend on their adhesive properties for selective interaction with the host cells [5].

Host-fungal interactions are inherently complex and dynamic. In order to identify new microbial targets and develop more effective antifungal therapies, it is important to understand the cellular and molecular mechanisms of the disease [6]. Recently, the 
implications of evolution for host-parasite interactions have led authors to investigate how heterogeneities in parasite virulence and host life-history may affect the persistence and spread of diseases in natural systems [7]. On the other hand, new virulence factors are being identified in many infectious microbes, and some research focuses on the relative contributions of virulence factors to pathogenesis [7, 8]. The characterization of some of these factors has demonstrated that virulence is complex and multifactorial [9]. Many fungal pathogens, such as $P$. brasiliensis, have multiple virulence factors that can damage host defenses, and thus, contribute to an overall virulence phenotype for that organism. At the moment, the attachment, colonization, and dissemination of the etiological agent are considered to be the crucial stages in the onset of disseminated mycosis $[10,11]$.

Many fungal genes have been described as probably involved in the survival of $P$. brasiliensis in the host. Among these genes are those that encode the proteins essential to the life of the fungus, and those encoding proteins indispensable to the interaction with the host, supplying a pathogenic phenotype [12-16]. However, up to now, none of these genes has been confirmed as important in fungal virulence. More efficient molecular genetic systems for transformation and gene expression have been described only recently, and these will provide new opportunities to study the role of $P$. brasiliensis genes in pathogenesis [17]. It is likely that this fungus will produce a plethora of virulence factors.

The adhesion of the infectious propagules of $P$. brasiliensis during infection of host cells is a crucial first step to subsequent invasion, colonization, and growth, in which various phenotypes (growth, invasion, and metastasis) are developed, depending on the fungal strain, the host, and other factors [10, 18-21]. Secondly, the internalization of yeast cells of $P$. brasiliensis by epithelial and endothelial cells has also been demonstrated [22, 23]. This could be a mechanism, by which the microorganisms gain access to the bloodstream and spread to other tissues.

\section{Interactions of epithelial and endothelial cells with $P$. brasiliensis}

The airway epithelium represents the primary site for contact between airborne microbes and their hosts.
During human infection with $P$. brasiliensis, the first cells to encounter the organisms may be alveolar macrophages and alveolar epithelial cells. Although epithelial cells serve as a relatively passive physical barrier to infection, they may contribute more actively to signaling events in the immune response. To cross tissue planes and cause invasive disease, the fungus must invade normally non-phagocytic host cells of the epithelium and endothelium [11]. The presence of typical yeasts of $P$. brasiliensis on and inside epithelial cells was first demonstrated 40 years ago [24]. This feature was observed in neutrophils and in the chorioallantoic membrane, as well as in mucocutaneous surfaces of infected human tissues. Structures were observed with a surrounding vacuole membrane and no cell wall, similar to the spheroplasts of $P$. brasiliensis [25]. Techniques that employ mammalian cell cultures can be used initially to give insights into host-parasite interaction. A cell line derived from human alveolar epithelial cells, A-549, has been used as an in vitro type II pulmonary epithelial cell model, as have Vero and HeLa cells $[26,27]$. These models have been developed to study the steps that occur between the initial contacts of $P$. brasiliensis, and the events that culminate in its entering the cell $[28,29]$. The adherence phenomenon varies among strains and correlates with their virulence [30]; strains that are more virulent in animals exhibit enhanced adhesion in vitro. In particular, $\mathrm{Pb} 18$, described as the most virulent strain in animals, adhered most strongly to Vero cells [28].

One isolate of $P$. brasiliensis ( $\mathrm{Pb} 113$ ) was seen to adhere to epithelial cells [31], and then apparently invade them. Initially, the yeast forms adhered to the epithelial cells and, some time later, were observed in the cytoplasm, close to the nucleus [22, 29]. The adhesion to the epithelial cells was accomplished by means of a small tube [26, 27], and alterations in the Vero cell membrane were then observed around the adhesion area, with fungal elements, forming depressions probably caused by extracellular products of the yeast, perhaps proteinases. Characteristic fungal and protoplast forms were observed inside the cells after $24 \mathrm{~h}$ of incubation (Figs. 1, 2). Some fungus has been observed enclosed in a vacuole membrane, suggesting phagocytosis [28]. The fungus probably enters the cell as a protoplast, and regenerates its cell wall in the host cytoplasm. This event requires further study. In HeLa cells, a similar phagocytosis was seen after 

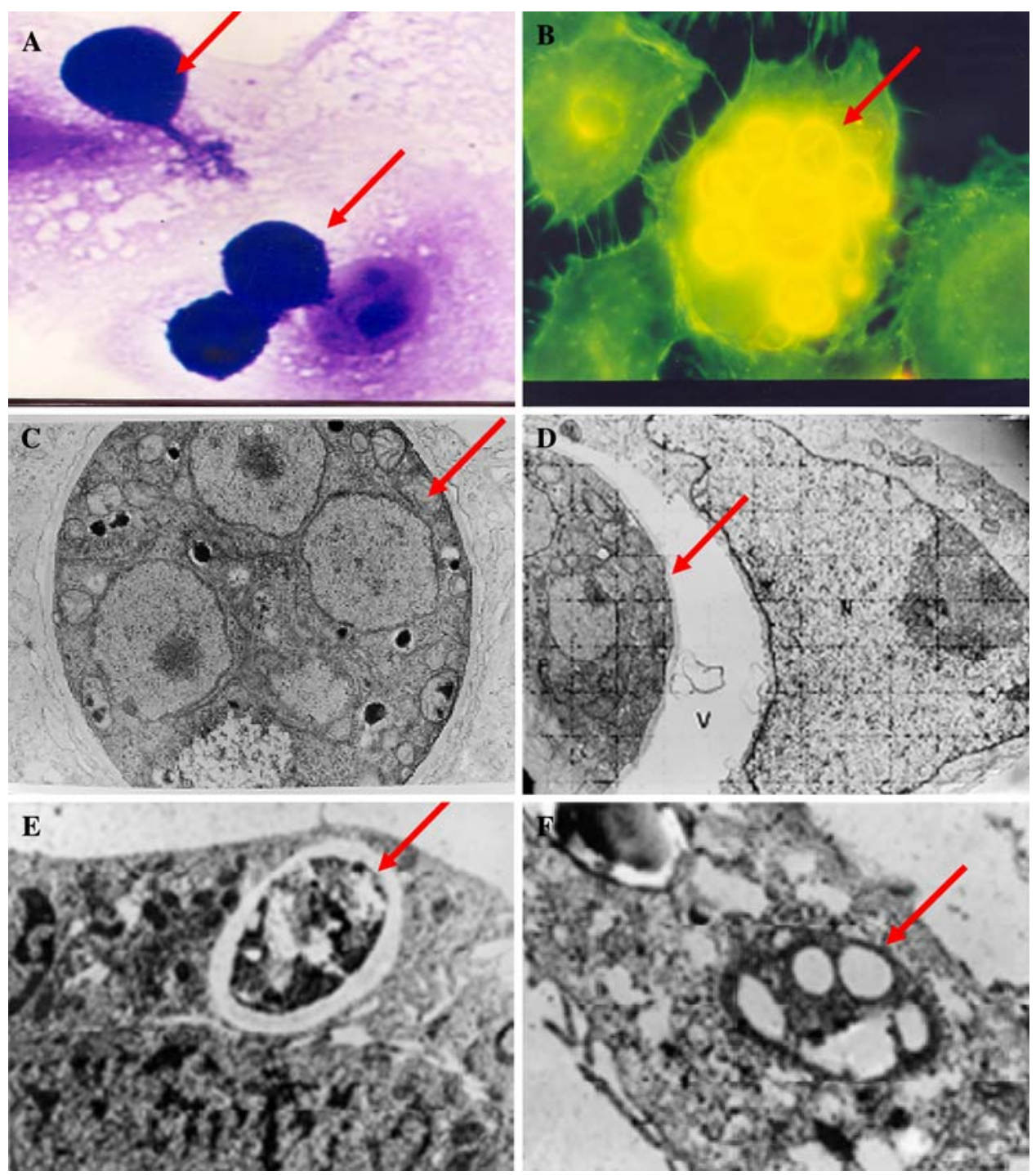

Fig. 1 Adhesion to and invasion of Vero cells by $P$. brasiliensis. (a) optical micrograph of adhering fungal cells stained with Giemsa; (b) invasion revealed by immunofluorescence microscopy; (c-f) SEM photomicrographs of

internalized $P$. brasiliensis, (d, e): surrounded by vacuoles, (f) protoplast forms after $24 \mathrm{~h}$ of incubation. The arrows indicate the presence of $P$. brasiliensis

P. brasiliensis adhesion. The process seems to involve great changes in both the host cell and the fungal cytoskeletons [27, 29], suggesting that the capacity of the fungal cells to be internalized may be important in the development of the disease, even though $P$. brasiliensis is not an essentially intracellular parasite [32]. Thus, epithelial and endothelial cells could be a reservoir for the fungus, protected from the macrophages, as has been demonstrated in other diseases $[10,11]$. The internalization of

P. brasiliensis by epithelial cells could be a mechanism for the yeast cells to evade the professional phagocytes, which might help in the dissemination of the pathogen $[19,25]$. Pulmonary epithelial cells are believed to play a crucial role in maintaining normal lung function. As the cells are strategically located at the interface between air and tissue, they primarily provide a morphological and functional barrier to the environment. In addition, airway epithelial cells clear the lung of extraneous material, while the alveolar 


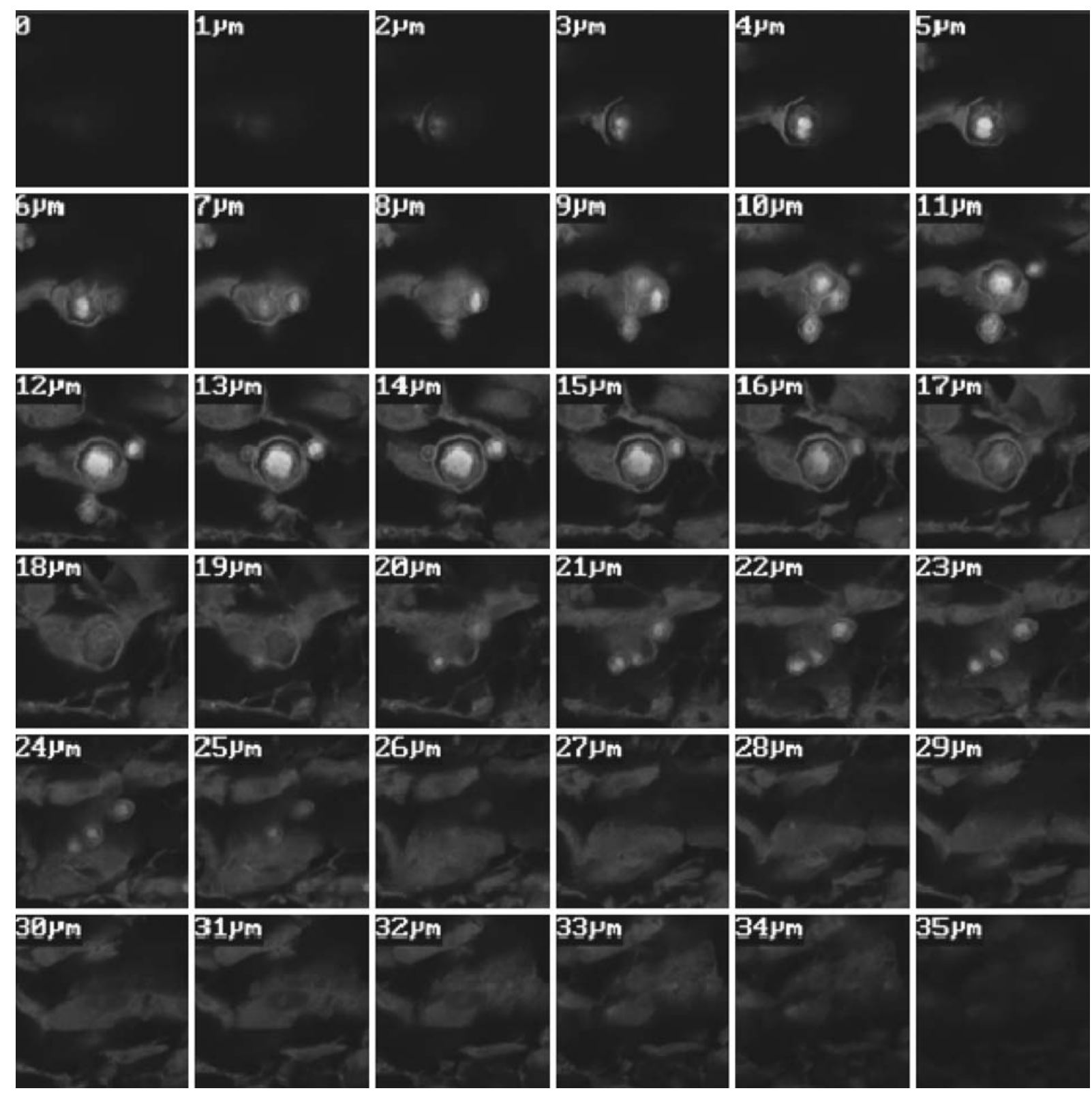

Fig. 2 Intracellular parasitism of $P$. brasiliensis in Vero cells after $5 \mathrm{~h}$ infection, shown in a laser confocal microscopy image gallery of 35 serial sections

epithelium is responsible for pulmonary gas exchange. However, recent data suggest that pulmonary epithelial cells may also modulate the inflammatory response to injurious agents [33].

On the other hand, migration of pathogenic yeasts to endothelial cells is considered a prerequisite for multiple organ invasion and dissemination of the fungus. We have investigated the adhesion of
P. brasiliensis to endothelial cells, as such adhesion could represent a mechanism of dissemination. It was very hard to observe $P$. brasiliensis in the act of adhering to an endothelial cell monolayer, when examined periodically, suggesting that migration of the fungus across the endothelial layer is very fast, and cannot normally be observed in cell culture in vitro. Additionally, an experiment on the migration of 
P. brasiliensis through an endothelial cell monolayer was carried out, and it was found that yeast cells migrated in greater numbers, and took less time, in control wells without cells. The fungus crossed the monolayer, but, the migration rate was about $30 \%$ lower than in control wells. This shows that the monolayer partially blocked migration of the fungus. Thus, $P$. brasiliensis can cross the endothelium rapidly, and probably invades deeper tissue. This model should be studied further to investigate the dissemination capacity of this fungus. During hematogenic dissemination, interactions of this nature constitute the first stages in the development of innumerable infections [34].

\section{Adherence molecules}

Molecules of adherence are fundamental in the pathogen-host interaction. These are usually exposed surface structures that facilitate adherence to host cells, or target host serum proteins of the extracellular matrix (ECM). During this interaction, the fungal cell wall is in continual contact with the host and acts as a sieve and reservoir of molecules such as adhesins [20, 35]. Our knowledge of the $P$. brasiliensis cell-surface structures and the basic mechanisms underlying their interaction with host receptor molecules has increased dramatically, through molecular and structural analysis of adherence molecules [20, 36].

Successful host tissue colonization by a fungus is a complex event, generally involving a ligand (adhesin) encoded by the pathogen and a cell receptor. The microorganism has the option of interacting with three types of host component: secreted cell products, host cell surface, or ECM proteins, such as types I and IV collagen, fibronectin, fibrinogen, and laminin. As described for bacteria [37], the search for new efficient treatments for systemic mycoses should be focused on the study of specific ligands or adhesins on the surface of the fungus that could adhere to various host substrata. Anti-adhesive drugs could then serve as a new way to fight infectious diseases.

Some of the receptors and ligands involved in the interaction of the fungus with the ECM have been identified at molecular level. The interactions of two samples of Pb18a (18a subcultured in PYG and 18b reisolated from infected hamster) were investigated with Vero cells and ECM proteins. Fungal cells bound to immobilized ECM proteins. Immunofluorescence labeling clearly demonstrated the presence of laminin, fibronectin, and type I and IV collagen binding sites on the surface of $P$. brasiliensis yeast cells. The reisolated sample (18b) demonstrated a higher capacity to bind to ECM proteins than the subcultured one (18a). Laminin was the most strongly bound component for both samples, followed by type I collagen, fibronectin, and type IV collagen for Pb18b. A remarkable difference was seen in the interaction of the two samples with fibronectin. Pb18a exhibited weaker binding to these ECM components. P. brasiliensis cell-free components (extracted from $\mathrm{Pb} 18 \mathrm{a}$ or 18b) also adhered differently to $40 \mathrm{kDa}$ and $120 \mathrm{kDa}$ fibronectin fragments, Pb18b components interacting significantly with the $120 \mathrm{kDa}$ fragment. Ligand affinity binding assays showed that type I collagen recognized two P. brasiliensis antigen components (47 and $80 \mathrm{kDa}$ ), and the major antigen gp43 bound both fibronectin and laminin [38].

This $43 \mathrm{kDa}$ glycoprotein, a laminin ligand, plays a role in the adhesion [39]. This fact was confirmed when anti-gp43 serum prevented $85 \%$ of the $P$. brasiliensis from binding to Vero cells [28]. The gp43 peptide 1 (NLGRDAKRHL), with several positively-charged amino acids, contributed most to the adhesion of P. brasiliensis to Vero cells. Peptides RGDS (43.5\%) in fibronectin, and CDPGYIGSR-NH2 (51.5\%) and YIGSR $(42.5 \%)$ in laminin showed the highest percentage inhibition of adhesion of gp43 to Vero cells [38].

Other fungal components also take part in the adhesion process [19]. Recently, a P. brasiliensis adhesin of $30 \mathrm{kDa}$ was isolated with the capacity to bind to laminin. This protein was more expressed in the $P$. brasiliensis isolate that possessed a higher adhesion capacity. Treatment of a monolayer of epithelial cells with these two laminin adhesins (30 and $43 \mathrm{kDa}$ ) inhibited $P$. brasiliensis adhesion to the cells. Thus, a combination of these two adhesins significantly decreases the adhesion and invasion indices [40]. P. brasiliensis also shows two cellsurface proteins, of 32 and $19 \mathrm{kDa}$ molecular mass that interact with several ECM proteins, such as laminin, fibronectin, and fibrinogen [41]. More recently, recombinant 3-glyceraldeyde phosphate dehydrogenase (GAPDH) from P. brasiliensis was found to be capable of binding to laminin, collagen I, and fibronectin. P. brasiliensis yeast forms treated 
with anti-GAPDH were inhibited from infecting epithelial cells, and pneumocytes treated with recombinant GAPDH were resistant to fungal infection [36]. Paracoccin, a recently described adhesin, interacted with laminin in a dose-dependent manner. This interaction was inhibited by $\mathrm{N}$-acetylglucosamine, followed by D-glucose and D-mannose, but not by D-galactose, $\mathrm{N}$-acetylgalactosamine, or L-fucose [42]. Finally, ligand-affinity binding assays showed that a protein of $54 \mathrm{kDa}(\mathrm{p} I$ 5.6) had the properties of a fibronectin-binding adhesin [43]. Proteomic approaches will allow the characterization of adhesins produced under different conditions. Recently, we evaluated the $\mathrm{Pb} 01$ isolate before $(\mathrm{Pb} 01 \mathrm{~A})$ and after $(\mathrm{Pb} 01 \mathrm{~B})$ passage in epithelial cultured cells, in relation to protein expression, adhesion, and capacity of its cell-free extract to bind to laminin and fibronectin. We detected 197 spots in Pb01B extracts, 41 in $\mathrm{Pb} 01 \mathrm{~A}$, and 19 matches. An increase in protein expression and the number of adhesins was evident in $\mathrm{Pb} 01 \mathrm{~B}$ after cell culture passage [44]. This occurrence could be associated with host adaptation and related to the virulence of $P$. brasiliensis [40, 45, 46]. Host-pathogen interactions reflect the balance of host defenses and pathogen virulence mechanisms. Advances in proteomic techniques now afford opportunities to compare protein content between complex biological systems ranging from cells to animals and clinical samples. A more in-depth study of hostpathogen interactions would improve our mechanistic understanding of pathogenicity and virulence, thereby defining novel therapeutic and vaccine targets.

The pathogen may regulate adhesin expression so as to survive and to produce illness. In P. brasiliensis, some adhesins have been described, and it is believed that all can play important roles in pathogenesis [20,36, 39-41]. However, until now we have no $P$. brasiliensis strains with modified genes for these adhesins. Such strains have been described effectively for Candida albicans [47, 48], C. glabrata [49], Blastomyces dermatitidis [50], and Coccidioides immitis [51], and it was confirmed that adhesins play a role as virulence factors. C. albicans with genetically modified adhesins was incapable of adhering to epithelial and endothelial cells $[47,52]$; equally, B. dermatitidis modified genetically in the main adhesin was unable to bind to pulmonary tissues [53, 54].

\section{Invasion process}

For many microbial pathogens, invasion of host cells is critical for the initiation and maintenance of infection, and many of these organisms have more than one mechanism to induce their own uptake by host cells [11, 55, 56]. Many of them can invade eukaryotic cells, and use this environment to multiply, to cross tissues and cause invasive disease, or to escape from the host immune response. Professional phagocytes and non-phagocytic cells, such as epithelial and normal endothelial cells, may be invaded [11, 57]. In many cases, cell invasion occurs because the microorganism induces its own uptake by these cells, specific extracellular signals stimulating cytoskeleton rearrangement at the point of contact with the microorganism. This rearrangement of cell microfilaments results in the endocytosis of the organism [58, 59]. Epithelial cells and fibroblasts do not encode CR3 receptors and, normally, they do not phagocytose. However, many intracellular pathogens are capable of entering these cells, by mechanisms involving integrins and cytoskeleton rearrangement. Bacterial pathogens manipulate the cytoskeleton of non-phagocytic eukaryotic cells to promote internalization, intracellular motility, and survival [60-62]. Some fungi that cause invasive disease, such as C. albicans, Cryptococcus neoformans, and Aspergillus fumigatus, invade host epithelial cells during mucosal and respiratory infection, and subsequently invade endothelial cells during hematogenous infection [11]. The pathogens can establish interactions with their hosts, and some have the ability to adhere, to invade, and to activate numerous signaling pathways. The study of the host-pathogen interaction supplies valuable data that help us to understand this diverse process. In $P$. brasiliensis, little is known about which pathways this fungus activates to survive and to escape from the monocyte-phagocyte system.

The invasion of A549 and Vero epithelial cells by $P$. brasiliensis has been shown to affect the cytoskeletal structure of the host cells, interfering in morphological aspects of the actin, tubulin, and cytokeratin components. Treatment with cytochalasin $\mathrm{D}$ and colchicine reduced the invasion index, indicating the functional participation of microfilaments and microtubules in this mechanism [22]. One plausible hypothesis is that $P$. brasiliensis expresses 
at least two different mechanisms of invasion, one microfilament-dependent and the other microtubuledependent. Expression of one or more fungal uptake pathways may depend on the presence of (so far unidentified) specific cell membrane receptors under particular environmental conditions and on the influence of other, surrounding cells. Why both pathways were observed in the same cell at the same time is at present hard to explain. However, the identity of any $P$. brasiliensis invasin or its epithelial receptor has not yet been discovered.

The fungus induces epithelial cells to produce pseudopodia (an actin-based movement of the cell surface) that engulf the organism and pull it into the cell. The formation of these pseudopodia is accompanied by the accumulation of epithelial cell microfilaments in the cytoplasm surrounding the organism. These microfilaments are required for endocytosis because disrupting them with cytochalasin D blocks this process. This mechanism is not used by all microorganisms, so it is considered as an important virulence factor. Some fungal species are known to be capable of invading mammalian cells in vitro and in vivi, but few studies have described the invasion process [11, 19, 22, 63-65].

On the other hand, the breakup of cytokeratin by $P$. brasiliensis may involve specific enzymes, possibly gp43 [66, 67], causing a loss of the filamentous structure. This degradation of cytokeratin could explain both the cell invasion process in vitro and the capacity of $P$. brasiliensis to cross epithelial barriers in vivi [10]. Perhaps the presence of specific fungal proteases plays an important role in the internalization and translocation of the fungus across epithelial barriers, as in Candida albicans [11].

The survival of $P$. brasiliensis in the intracellular environment may provide it with a protective mechanism against components involved in the immune response and the action of antifungal therapies. Microbial pathogens may enhance their ability to persist in infected hosts by causing the death of cells required for host defense. Although some intracellular pathogens may employ strategies to prevent cell death during pathogen replication, their subsequent escape and dissemination to new host cells may gradually require cell lysis. Apoptosis has important roles in organ development, cell differentiation, and the maintenance of homeostasis. However, it is speculated that there may be advantages for the host in the modulation of apoptosis, since non-professional phagocytes do not possess efficient microbicidal machinery, as do macrophages, and the death of these cells would not compromise the homeostasis of the organism. On the other hand, the death of cells with $P$. brasiliensis yeast cells inside could provide a route for dissemination to distant sites, such as a metastatic focus. Another hypothesis is that apoptotic cells with fungus inside would serve as a vehicle for gaining entry into macrophages without stimulating the microbicidal activities. If these ideas are correct, the succession of events in epithelial cells infected with $P$. brasiliensis in vitro would be fungal adhesion, translocation to the cell cytoplasm, multiplication, and induction of apoptosis. The correlation with pathogenic mechanisms in vivi could elucidate the initial steps of the infection [23]. By inducing apoptosis in macrophages, the microorganism could accomplish two goals: first, to kill the microbicidal cells in the tissues efficiently, and thus prevent its own death; second, to stimulate the inflammatory response and invade the tissues as a consequence of the damage caused by this response [68, 69].

We demonstrated that gp43 induced high levels of apoptosis in peripheral blood mononuclear cells [20]. In cultures of mononuclear cells from the peripheral system of patients with paracoccidioidomycosis, stimulated with gp43, IL-10 levels were found to be high and the addition of anti-IL-10 to these cultures increased the rate of apoptosis in cells stimulated only with gp43, suggesting an IL-10 anti-apoptotic role [70]. Studies in mice infected with $P$. brasiliensis showed that it can invade the thymus, inducing severe atrophy, caused by programmed cell death, suggesting that such alterations may be involved in the phenomenon of immunosuppression frequently associated with paracoccidioidomycosis [71]. MendesGiannini and collaborators [22] observed that $P$. brasiliensis induces apoptosis in epithelial cells. However, the fungus remained viable inside these cells, and multiplied. Expression of Bak and Bcl-2, the pro and anti-apoptosis signals, was not modified in the cells for up to $24 \mathrm{~h}$ of infection, suggesting a competition between survival and death mechanisms that allowed the infection to persist. High expression of Bak was observed after $48 \mathrm{~h}$, indicating a loss of the competition by the survival signals. The mechanisms of invasion of host cells, persistence within them, and the subsequent induction of apoptosis of 
such cells may explain the efficient dissemination of P. brasiliensis.

Many pathogens are capable of manipulating apoptosis in host cells, depending on the strain; the advantages of this manipulation may serve the pathogen or the host. Danelishvili et al. [72] have shown that Mycobacterium tuberculosis interacts with macrophages and epithelial cells in the lung alveolar space, where it is able to invade and multiply in these cells. Both virulent and attenuated strains of M. tuberculosis induced apoptosis in macrophages; however, the attenuated strain induced more apoptosis after 5 days of infection. In the epithelial cells, necrosis was observed more than apoptosis. Phagocyte apoptosis has been proposed as a strategy of the host to prevent the progress of the infection by causing the death of intracellular microorganisms. However, this can also allow the microorganisms to escape and infect neighboring cells, and spread to other tissues. P. brasiliensis is a more extracellular than intracellular pathogen $[32,73]$, and its escape to the intracellular compartment could favor its dissemination, while in histoplasmosis, fungus remains inside the apoptotic bodies and is destroyed [74]. Therefore, the mechanisms of invasion of the host cell, persistence inside the cell, and the subsequent induction of apoptosis of this same cell, may explain the efficient behavior of $P$. brasiliensis in promoting tissue infection and/or dissemination in the bloodstream. The invasion of normally non-phagocytic host cells can thus have different consequences, depending on the type of invading fungus. Aspergillus fumigatus blocks apoptosis of pulmonary epithelial cells [75], whereas $P$. brasiliensis induces apoptosis of epithelial cells [22], showing that the same host response can result in different parasitehost responses. One question not answered, refers to the fact that patients with paracoccidioidomycosis often present pulmonary fibrosis and exhibit severe respiratory limitations [76]. Fibrosis was attributed mainly to the progressive evolution of the granulomata toward cicatrization and to a lesser degree, probably, to direct induction by the fungus. Today, it is known that pulmonary fibrosis is characterized by the loss of lung epithelial cells and the proliferation of fibroblasts. In recent years, the topic of apoptosis in the lung has received a burst of attention from scientists fascinated by the cells of the vascular endothelium, epithelium, and immune system and interstitial cell populations. With regard to the epithelium, the initial demonstration by Fine et al. [77] that alveolar epithelial cells express functional Fas (CD95, APO1), was followed rapidly by the finding of Hagimoto et al. [78] that activation of Fas in vivo could induce epithelial apoptosis followed by fibrosis. The relationship between apoptosis and fibrosis in pulmonary paracoccidioidomycosis has not yet been studied.

Pathogens have developed a diversity of strategies to interact with host cells, manipulate their behavior, and thus, to survive and propagate [79]. During these processes, a great number of signaling pathways are activated. Using in silico search of the $P$. brasiliensis transcriptome-expressed sequence tag database for components of signaling pathways, several protein cascades in $P$. brasiliensis were described, such as (i) mitogen-activated protein kinase signaling for cell integrity, cell-wall construction, pheromone/mating and osmoregulation, (ii) the cAMP/PKA system, which regulates fungal development and virulence, (iii) the Ras protein, which allows cross-talk between cascades, (iv) calcium-calmodulin-calcineurin, which controls cell survival under oxidative stress, high temperature, and membrane/cell-wall perturbation, and (v) the target of the rapamycin pathway, controlling cell growth and proliferation. However, little is known on which pathway is activated to survive and to escape from the machinery of the host cells. Marques and co-workers [80] have identified four genes, RHO1, SEP1, FLB1, and PCK1, which encode proteins involved in cell signaling and polarity establishment in $P$. brasiliensis. Interestingly, RHO1 was expressed at 10- to 15 -fold higher levels in minimal medium than in complete medium. De Carvalho and co-workers [81] reported that the $\mathrm{Ca}^{2+} /$ calmodulin signaling pathway has pleiotropic intracellular effects, acting on systems such as the cytoskeleton, and regulating nuclear transcription factors that may affect the expression level of other genes. In $P$. brasiliensis, this pathway could be involved in the regulation of genes differentially expressed in the yeast and mycelial forms. Single fragments were identified by Southern blot, suggesting that the $P$. brasiliensis calmodulin gene is probably a single copy, as in other fungi such as H. capsulatum [82] and C. albicans [83].

Recently, Monteiro da Silva et al. [84] observed that fungal invasion was significantly inhibited after 
pretreatment of epithelial cells with genistein, a specific tyrosine kinase inhibitor, indicating that the tyrosine kinase pathway is involved in $P$. brasiliensis internalization. In contrast, when the fungus was treated, a slight (not significant) inhibition of PTK was observed, suggesting that PTK might not be the fungus' transduction signal pathway during the invasion process of epithelial cells. Intense PTK immunofluorescence labeling was observed at the border of the $P$. brasiliensis infected cells, and little PTK labeling was found in either uninfected cells or yeast cells, at later infection times ( 8 and $24 \mathrm{~h}$ ). Moreover, when the epithelial cells were treated with genistein and then infected with $P$. brasiliensis, no labeling was observed, suggesting the importance of the PTK in the infectious process. These results suggest that the PTK pathway participates in the transduction signal during the initial events of the adhesion and invasion of mammalian epithelial cells by $P$. brasiliensis.

The signaling pathways involved in the cell proliferation, growth, and cytosol signals associated with the cytoskeleton during the invasion of epithelial cells by $P$. brasiliensis were mediated by actin rearrangement, and some virulence factors target the Rho family (Rho, Rac, and Cdc42), which are essential regulators of actin reorganization. Thus, the entry of $P$. brasiliensis into the epithelial cell can apparently require the activation of the small family of Rho GTPases, as demonstrated in a recent study [85]. In conclusion, in relation to this fungus, there is a need for more information on which proteins induce invasion, the host cell receptor, to which these endocytosis-inducing proteins bind, and the host cell signal transduction mechanisms that govern fungal invasion. However, we expect that the invasion mechanisms of $P$. brasiliensis will be more clearly elucidated in the near future.

Acknowledgments We thank Dr. Henrique Leonel Lenzi, for the Confocal images (Depto. de Patologia, Instituto Oswaldo Cruz-Fiocruz, Rio de Janeiro, RJ. Brazil).

\section{References}

1. Benard G, Franco M. Paracoccidioidomycosis. In: Merz WG, Hay RJ editors. Topley Wilson's medical mycology. 10, 13th ed. London: Hodder Arnold; 2005.

2. Franco M. Host-parasite relationships in paracoccidioidomycoses. J Med Vet Mycol. 1986;25:5-18.
3. Kurokawa CS, Lopes CR, Sugizaki MF, Kuramae EE, Franco MF, Peracoli MT. Virulence profile of ten Paracoccidioides brasiliensis isolates: association with morphologic and genetic patterns. Rev Inst Med Trop Sao Paulo. 2005;47:257-62.

4. Franco CS, Lacaz A, Restrepo-Moreno G, Del Negro, editors. Paracoccidioidomycosis. Boca Raton: CRC Press; 1994.

5. Dranginis AM, Rauceo JM, Coronado JE, Lipke PN. A biochemical guide to yeast adhesins: glycoproteins for social and antisocial occasions. Microbiol Mol Biol Rev. 2007;71:282-94.

6. Cutler JE, Deepe GS, Klein BS. Advances in combating fungal diseases: vaccines on the threshold. Nat Rev Microbiol. 2007;5:13-28.

7. Zhang P, Sandland GJ, Feng Z, Xu D, Minchella DJ. Evolutionary implications for interactions between multiple strains of host and parasite. J Theor Biol. 2007;14:54155.

8. McClelland EE, Bernhardt P, Casadevall A. Estimating the relative contributions of virulence factors for pathogenic microbes. Infect Immun 2006;74:1500-04.

9. Rappleye CA, Goldman WE. Defining virulence genes in the dimorphic fungi. Annu Rev Microbiol. 2006;60:281303.

10. Mendes-Giannini MJ, Soares CP, Monteiro da Silva JL, Andreotti PF. Interaction of pathogenic fungi with host cells: Molecular and cellular approaches. FEMS Immunol Med Microbiol. 2005;45:383-94.

11. Filler SG, Sheppard DC. Fungal invasion of normally nonphagocytic host cells. PLoS Pathog. 2006;2:e129.

12. Bailão AM, Schrank A, Borges CL, Dutra V, MolinariMadlum EE, Soares Felipe MS, Soares Mendes-Giannini MJ, Martins WS, Pereira M, Soares CM. Differential gene expression by Paracoccidioides brasiliensis in host interaction conditions: representational difference analysis identifies candidate genes associated with fungal pathogenesis. Microb Infect. 2006;8:2686-97.

13. Bastos KP, Bailão AM, Borges CL, Faria FP, Felipe MS, Silva MG, Martins WS, Fiúza RB, Pereira M, Soares CM. The transcriptome analysis of early morphogenesis in Paracoccidioides brasiliensis mycelium reveals novel and induced genes potentially associated to the dimorphic process. BMC Microbiol. 2007;7:29.

14. Felipe MS, Andrade RV, Arraes FB, Nicola AM, Maranhão AQ, Torres FA, Silva-Pereira I, Poças-Fonseca MJ, Campos EG, Moraes LM, Andrade PA, Tavares AH, Silva SS, Kyaw CM, Souza DP, Pereira M, Jesuíno RS, Andrade EV, Parente JA, Oliveira GS, Barbosa MS, Martins NF, Fachin AL, Cardoso RS, Passos GA, Almeida NF, Walter ME, Soares CM, Carvalho MJ, Brígido MM. Transcriptional profiles of the human pathogenic fungus Paracoccidioides brasiliensis in mycelium and yeast cells. J Biol Chem. 2005;280:24706-14.

15. Goldmann GH, Dos Reis Marques E, Duarte Ribeiro DC, de Souza Bernardes LA, Quiapin AC, Vitorelli PM, Savoldi M, Semighini CP, de Oliveira RC, Nunes LR, Travassos LR, Puccia R, Batista WL, Ferreira LE, Moreira JC, Bogossian AP, Tekaia F, Nobrega MP, Nobrega FG, Goldman MH. Expressed sequence tag analysis of the human pathogen Paracoccidioides brasiliensis yeast phase: identification of 
putative homologues of Candida albicans virulence and pathogenicity genes. Eukaryot Cell. 2003;2:34-48.

16. Tavares AH, Silva SS, Dantas A, Campos EG, Andrade RV, Maranhão AQ, Brígido MM, Passos-Silva DG, Fachin AL, Teixeira SM, Passos GA, Soares CM, Bocca AL, Carvalho MJ, Silva-Pereira I, Felipe MS. Early transcriptional response of Paracoccidioides brasiliensis upon internalization by murine macrophages. Microb Infect. 2007;9:583-90.

17. Almeida AJ, Carmona JA, Cunha C, Carvalho A, Rappleye CA, Goldman WE, Hooykaas PJ, Leão C, Ludovico P, Rodrigues F. Towards a molecular genetic system for the pathogenic fungus Paracoccidioides brasiliensis. Fungal Genet Biol. 2007.

18. Borges-Walmsley MI, Chen D, Shu X, Walmsley AR. The pathobiology of Paracoccidioides brasiliensis. Trends Microbiol. 2002;10:80-87.

19. Mendes-Giannini MJS, Taylor ML, Bouchara JB, Burger E, Calich VLG, Escalante ED, Hanna SA, Lenzi HL, Machado MP, Miyaji M, Monteiro Da Silva JL, Mota EM, Restrepo A, Restrepo S, Tronchin G, Vincenzi LR, Xidieh $\mathrm{CF}$, Zenteno E. Pathogenesis II: fungal responses to host responses: interaction of host cells with fungi. Med Mycol. 2000;38:113-23.

20. Gonzalez A, Lenzi HL, Motta EM, Caputo L, Sahaza JH, Cock AM, Ruiz AC, Restrepo A, Cano LE. Expression of adhesion molecules in lungs of mice infected with Paracoccidioides brasiliensis conidia. Microb Infect. 2005;7:666-73.

21. Verstrepen KJ, Klis FM. Flocculation, adhesion and biofilm formation in yeasts. Mol Microbiol. 2006;60:5-15.

22. Mendes-Giannini MJS, Hanna SA, Monteiro Da Silva JL, Andreotti PF, Benard G, Lenzi HL, Soares CP. Invasion of epithelial mammalian cells by Paracoccidioides brasiliensis leads to cytoskeletal rearrangement and apoptosis of the host cell. Microb Infect. 2004;6:882-91.

23. Monteiro da Silva JL. Adesão e invasão de Paracoccidioides brasiliensis em cultura de células: envolvimento do citoesqueleto, evento de sinalização e ocorrência de apoptose [Tese]. Araraquara, São Paulo: Universidade Estadual Paulista; 2004. p. 134.

24. Furtado JS, Brito T, Freymuller E. The structure and reproduction of Paracoccidioides brasiliensis in human tissue. Sabouraudia. 1967;5:226-9.

25. De Brito T, Furtado JS, Castro RM, Manini M. Intraepithelial parasitism as an infection mechanism in human paracoccidioidomycosis. Vir Arch Path Anat. 1973;361:129-38.

26. Hanna SA. Estudo dos mecanismos e fatores de virulência de Paracoccidioides brasiliensis em culturas de células [Dissertação]. Rio Claro, São Paulo: Universidade Estadual Paulista; 1995. p. 166.

27. Uemura MA. Evidências da participação dos mecanismos de adesão e invasão celular na patogenicidade do Paracoccidioides brasiliensis [Dissertação]. Campinas, São Paulo: Universidade Estadual de Campinas; 1996. p. 99.

28. Hanna AS, Monteiro Da Silva JL, Mendes-Giannini MJS. Adherence and intracellular parasitism of Paracoccidioides brasiliensis in Vero cells. Microb Infect. 2000;2:1-8.

29. Mendes-Giannini MJS, Ricci LC, Uemura M, Toscano E, Arns CW. Infection and apparent invasion of Vero cells by Paracoccidioides brasiliensis. J Med Vet Mycol. 1994;32:189-95.
30. Hahn RC, Macedo AM, Fontes CJ, Batista RD, Santos NL, Hamdan JS. Randomly amplified polymorphic DNA as a valuable tool for epidemiological studies of Paracoccidioides brasiliensis. J Clin Microbiol. 2003;7:2849-54.

31. Mendes-Giannini MJS, Ricci LC, Uemura MA, Toscano E, Arns CW. Invasion of Vero cells by Paracoccidioides brasiliensis. Rev Arg Micol. 1992;15:29-36.

32. Tuder RM, El Ibrahim R, Godoy CE, De Brito T. Pathology of the human pulmonary paracoccidioidomycosis. Mycopathologia. 1985;92:179-88.

33. Kroegel C, Costabel U. Immune functions of constitutive pulmonary cells: the salt in the soup. Eur Respir J. 1994;7:2106-7.

34. Monteiro Da Silva JL, Andreotti PF, Mendes-Giannini MJS. Interação de Paracoccidioides brasiliensis com células endoteliais. Revista de Ciências Farmacêuticas Básica e Aplicada 2005;26:149-56.

35. Barbosa MS, Bao SN, Andreotti PF, De Faria FP, Felipe MS, Dos Santos Feitosa L, Mendes-Giannini MJ, Soares CM. Glyceraldehyde-3-phosphate dehydrogenase of Paracoccidioides brasiliensis is a cell surface protein involved in fungal adhesion to extracellular matrix proteins and interaction with cells. Infect Immun. 2006;74:382-9.

36. Moreira AP, Campanelli AP, Cavassani KA, Souto JT, Ferreira BR, Martinez R, Rossi MA, Silva JS. Intercellular adhesion molecule- 1 is required for the early formation of granulomas and participates in the resistance of mice to the infection with the fungus Paracoccidoides brasiliensis. Am J Pathol. 2006;169:1270-81.

37. Ofek I, Kahane I, Sharon N. Toward anti-adhesion therapy for microbial diseases. Trends Microbiol. 1996;4:297-9.

38. Mendes-Giannini MJ, Andreotti PF, Vincenzi LR, Monteiro Da Silva JL, Lenzi HL, Benard G, ZancopeOliveira R, De Matos Guedes HL, Soares CP. Binding of extracellular matrix proteins to Paracoccidioides brasiliensis. Microb Infect. 2006;8:1550-9.

39. Vicentini AP, Gesztesi JL, Franco MF, De Souza W, De Moraes JZ, Travassos LR, Lopes JD. Binding of Paracoccidioides brasiliensis to laminin through surface glycoprotein gp43 leads to enhancement of fungal pathogenesis. Infect Immun. 1994;62:1465-9.

40. Andreotti PF, Monteiro Da Silva JL, Bailão AM, De Almeida Soares CM, Benard G, Soares CP, MendesGiannini MJS. Isolation and partial characterization of a $30 \mathrm{kDa}$ adhesin from Paracoccidioides brasiliensis. Microb Infect. 2005;7:875-81.

41. Gonzalez A, Gomez B, Diez S, Hernandez O, Restrepo A, Hamilton AJ, Cano LE. Purification and partial characterization of a Paracoccidioides brasiliensis proteins with capacity to bind to extracellular matrix proteins. Infect Immun. 2005;73:2486-95.

42. Coltri KC, Casabona-Fortunato AS, Gennari-Cardoso ML, Pinzan CF, Ruas LP, Mariano VS, Martinez R, Rosa JC, Panunto-Castelo A, Roque-Barreira MC. Paracoccin, a GlcNAc-binding lectin from Paracoccidioides brasiliensis, binds to laminin and induces TNF-alpha production by macrophages. Microb Infect. 2006;3:704-13.

43. Donofrio FC. Isolamento e caracterização parcial de adesina de Paracoccidioides brasiliensis ligante de fibronectina. [Dissertação]. Araraquara, São Paulo: Universidade Estadual Paulista; 2007. p. 108. 
44. Silva JF, Andreotti PF, Monteiro da Silva JL, Soares CM, Mendes-Giannini, MJS. Proteomic analysis of Paracoccidioides brasiliensis adhesins correlated with adhesion profile. Salvador, 36nd SBBq, 2007. Abstract No: W-50.

45. Castaneda E, Brummer E, Pappagianis D, Stevens DA. Chronic pulmonary and disseminated paracoccdioidomycosis in mice: quantitation of progression and chronicity. $\mathbf{J}$ Med Vet Mycol. 1987;23:377-87.

46. San-Blas G, San-Blas F, Ormaechea E, Serrano LE. Cell wall analysis of adenine requiring mutant of the yeast like form of Paracoccidioides brasiliensis strain IVICPb9. Sabouraudia. 1977;15:297-303.

47. Sundstrom P, Cutler JE, Staab JF. Reevaluation of the role of HWP1 in systemic candidiasis by use of Candida albicans strains with selectable marker URA3 targeted to the ENO1 locus. Infect Immun. 2002;70:3281-3.

48. Zhao X, Oh SH, Cheng G, Green CB, Nuessen JA, Yeater K, Leng RP, Brown AJ, Hoyer LL. ALS3 and ALS8 represent a single locus that encodes a Candida albicans adhesin: functional comparisons between Als3p and Als1p. Microbiology. 2004;15:2415-28.

49. Cormack BP, Ghori N, Falkow S. An adhesin of the yeast pathogen Candida glabrata mediating adherence to human epithelial cells. Science. 1999;285:578-82.

50. Brandhorst T, Wuthrich M, Finkel-Jimenez B, Klein B. A C-terminal EGF-like domain governs BAD1 localization to the yeast surface and fungal adherence to phagocytes, but is dispensable in immune modulation and pathogenicity of Blastomyces dermatitidis. Mol Microbiol. 2003;48:53-65.

51. Hung CY, Yu JJ, Seshan KR, Reichard U, Cole GT. A parasitic phase-specific adhesin of Coccidioides immitis contributes to the virulence of this respiratory fungal pathogen. Infect Immun. 2002;70:3443-56.

52. Sundstrom P. Adhesins in Candida albicans. Curr Opin Microbiol. 1999;4:353-7.

53. Brandhorst TT, Wuthrich M, Warner T, Klein B. Targeted gene disruption reveals an adhesin indispensable for pathogenicity of Blastomyces dermatitidis. J Exp Med. 1999;189:1207-16.

54. Klein BS. Molecular basis of pathogenicity in Blastomyces dermatitidis: the importance of adhesion. Curr Opin Microbiol. 2000;4:339-43.

55. Pizarro-Cerda J, Cossart P. Bacterial adhesion and entry into host cells. Cell 2006;124:715-27.

56. Phan QT, Myers CL, Fu Y, Sheppard DC, Yeaman MR, Welch WH, Ibrahim AS, Edwards JE, Filler SG. Als3 is a Candida albicans invasin that binds to cadherins and induces endocytosis by host cells. PLoS Biol. 2007;20:e64.

57. Finlay BB, Falkow S. Common themes in microbial pathogenicity revisited. Microbiol Mol Biol Rev. 1997;61:136-69.

58. Swanson JA, Watts C. Macropinocytosis. Trends Cell Biol. 1995;5:424-8.

59. Swanson JA, Baer SC. Phagocytosis by zyppers and triggers. Trends Cell Biol. 1995;5:89-93.

60. Goldberg MB, Sansonetti PJ. Shigella subversion of the cellular cytoskeleton a strategy of epithelial colonization. Infect Immun. 1993;61:4941-6.

61. Hayward RD, Koronabis V. Direct nucleation and bundling of actin by the SipC protein of invasive Salmonella. Embo J. 1999;18:4926-34.
62. Rosenshine I, Duronio V, Finlay BB. Tyrosine protein kinase inhibitors block invasin-promoted bacterial uptake by epithelial cells. Infect Immun. 1992;60:2211-7.

63. Tsarfaty I, Sandovsky-Losica H, Mittelman L, Berdicevsky I, Segal E. Cellular actin is affected by interaction with Candida albicans. FEMS Microbiol Lett. 2000;189:22532.

64. Wasylnka JA, Moore MM. Uptake of Aspergillus fumigatus conidia by phagocytic and nonphagocytic cells in vitro: quantitation using strains expressing green fluorescent protein. Infect Immun. 2002;70:3156-63.

65. Kogan TV, Jadoun J, Mittelman L, Hirschberg K, Osherov N. Involvement of secreted Aspergillus fumigatus proteases in disruption of the actin fiber cytoskeleton and loss of focal adhesion sites in infected A549 lung pneumocytes. J Infect Dis. 2004;11:1965-73.

66. Mendes-Giannini MJS, Moraes RA, Ricci TA. Proteolytic activity of the 43,000 molecular weight antigen secreted by Paracoccidioides brasiliensis. Rev Inst Med Trop. 1990;32:384-5.

67. Puccia R, Carmona AK, Gesztesi JL, Juliano L, Travassos LR. Exocellular proteolytic activity of Paracoccidioides brasiliensis: cleavage of components associated with the basement membrane. Med Mycol. 1998;36:354-8.

68. Bayles KW, Wesson CA, Liou LE, Fox LK, Bohach A, Trumble WR. Intracellular Staphylococcus aureus escapes the endosome and induces apoptosis in epithelial cells. Infect Immun. 1998;66:336-42.

69. Lewis K. Programmed death in bacteria. Microbiol Mol Biol Rev. 2000;64:503-14.

70. Cacere CR, Romano CC, Mendes-Giannini MJS, Duarte AJ, Benard G. The role of apoptosis in the antigen-specific $\mathrm{T}$ cell hyporesponsiveness of paracoccidioidomycosis patients. Clin Immunol. 2002;105:215-22.

71. Souto PC, Brito VN, Gameiro J, da Cruz-Hofling MA, Verinaud L. Programmed cell death in thymus during experimental paracoccidioidomycosis. Med Microbiol Immunol. 2003;192:225-9.

72. Danelishvili L, Mc Garvey JLY, Bermudez LE. Mycobacterium tuberculosis infection causes different levels of apoptosis and necrosis in humam macrophages and alveolar epithelial cells. Cell Microbiol. 2003;5:649-60.

73. Lenzi HL, Calich VLG, Mendes-Giannini MJS, Xidieh CF, Miyaji M, Mota EM, Machado MP, Restrepo A. Two patterns of extracellular matrix expression in experimental paracoccidioidomycosis. Med Mycol. 2000;38:115-9.

74. Allen HL, Deepe GS Jr. Apoptosis modulates protective immunity to the pathogenic fungus Histoplasma capsulatum. J Clin Invest. 2005;10:2875-85.

75. Berkova N, Lair-Fulleringer S, Femenia F, Huet D, Wagner MC, Gorna K, Tournier F, Ibrahim-Granet O, Guillot J, Chermette R, Boireau P, Latge JP. Aspergillus fumigatus conidia inhibit tumour necrosis factor- or staurosporineinduced apoptosis in epithelial cells. Int Immunol. 2006;18:139-50.

76. Cock AM, Cano LE, Vélez D, Aristizábal BH, Trujillo J, Restrepo A. Fibrotic sequelae in pulmonary paracoccidioidomycosis: histopathological aspects in BALB/c mice infected with viable and non-viable Paracoccidioides brasiliensis propagules. Rev Inst Med Trop Sao Paulo. 2000;42:59-66. 
77. Fine A, Anderson NL, Rothstein TL, Williams MC, Gochuico BR. Fas expression in pulmonary alveolar type II cells. Am J Physiol. 1997;273:64-71.

78. Hagimoto N, Kuwano K, Kawasaki M, Yoshimi M, Kaneko Y, Kunitake R, Maeyama T, Tanaka T, Hara N. Induction of interleukin-8 secretion and apoptosis in bronchiolar epithelial cells by Fas ligation. Am J Respir Cell Mol Biol. 1999;21:436-45.

79. Lengeler KB, Davidson RC, D'souza C, Harashima T, Shen W, Wang P, Pan X, Waugh M, Heitman J. Signal transduction cascades regulating fungal development and virulence. Microbiol Mol Biol Rev. 2000;64:746-85.

80. Marques ER, Ferreira ME, Drummond RD, Felix JM, Menossi M, Savoldi M, Travassos LR, Puccia R, Batista WL, Carvalho KC, Goldman MH, Goldman GH. Identification of genes preferentially expressed in the pathogenic yeast phase of Paracoccidioides brasiliensis, using suppression subtraction hybridization and differential macroarray analysis. Mol Genet Genomics. 2004;271:667-777.
81. De Carvalho MJ, Amorim Jesuino RS, Daher BS, SilvaPereira I, de Freitas SM, Soares CM, Felipe MS. Functional and genetic characterization of calmodulin from the dimorphic and pathogenic fungus Paracoccidioides brasiliensis. Fungal Genet Biol. 2003;39:204-10.

82. El-Rady, Shearer Jr G. Isolation and characterization of a calmodulin-encoding cDNA from the pathogenic fungus Histoplasma capsulatum. J Med Vet Mycol. 1996;34:163-9.

83. Saporito SM, Sypherd PS. The isolation and characterization of a calmodulin encoding gene (CMD1) form the dimorphic fungus Candida albicans. Gene 1991;106:43-9.

84. Monteiro da Silva JL, Andreotti PF, Benard G, Soares CP, Miranda ET, Mendes-Giannini MJ. Epithelial cells treated with genistein inhibit adhesion and endocytosis of Paracoccidioides brasiliensis. Antonie Van Leeuwenhoek. 2007;92:129-35.

85. Toscano EM. Influência da gp43 kDa de P. brasiliensis em eventos de sinalização celular [Tese]. Araraquara, São Paulo: Universidade Estadual Paulista; 2006. p. 125. 